\title{
PERANCANGAN SET POT DEKORASI RUMAH DENGAN PENDEKATAN KEBUTUHAN USER MELALUI KONSEP SPACE ODYSSEY PADA PT. ARTES INDONESIA
}

\author{
Livia Fitrianti $^{1 *}$, Hardy Adiluhung ${ }^{2 *}$, Teuku Zulkarnain Muttaqien ${ }^{3 *}$
}

\author{
Program Studi Desain Produk S1 Fakultas Industri Kreatif \\ Universitas Telkom \\ Jl. Telekomunikasi, No. 1, Terusan Buahbatu-Bojongsoang, Kec. Dayeuhkolot, Kota Bandung, \\ Kode Pos 40257 \\ Jawa Barat. Indonesia \\ Email : liviafitrianti@students.telkomuniversity.ac.id, hardyadil@telkomuniversity.co.id, \\ tzulkarnainm@telkomuniversity.ac.id
}

\begin{abstract}
Abstrak
Selama masa pandemi kebiasaan masyarakat telah sepenuhnya berubah. Dari yang biasa melakukan aktivitas sehari-sehari berada diluar seperti bekerja dan bersekolah selama masa pandemi ini seluruh kegiatan dilakukan di rumah. Sehingga menciptakan kebiasaan baru dikalangan masyarakat salah satunya yaitu bertanam yang mengumpulkan tanaman hias dan juga mendekorasi ulang rumah untuk mendapatkan suasana baru dan membuat rumah lebih nyaman. Dalam memenuhi kebutuhan kebiasaan baru masyarakan diperlukan berbergai bentuk pot untuk menanam tanaman hias. Bertanam dalam ruangan membutuhkan sebuah pot yang memilik fokus utama sebagai penambah nilai keindahan ruangan lalu kemudian diikuti dengan nilai fungsi. Sehingga penulis menciptakan produk set pot dengan berbagai macam dan bentuk dengan konsep space odyssey. Penelitian ini digunakan dengan metode perancangan dengan pendekatan kuantitatif yang menghasilkan perancangan dimana proses penelitian mengikuti prosedur yang telah direncanakan, dengan konsep space odyssey. Hal ini mendukung aspek visual, material, dan manfaat sebagai analisis perancangan melalui metode SCAMPER dengan pembahasan analisis perancangan menggunakan TOR (Terms of Reference). Perancangan produk ini juga mengacu pada kegiatan bertanaman dalam ruangan yang mempunyai manfaat untuk kesehatan.
\end{abstract}

Kata Kunci: space odyssey, bertanam, pot, dekorasi.

\begin{abstract}
During the pandemic, people's habits have completely changed. From those who usually carry out daily activities outside such as work and school during this pandemic, all activities are carried out at home. Thus creating new habits among the community, one of which is planting which collects ornamental plants and also redecorating the house to get a new atmosphere and make the house more comfortable. In meeting the needs of the community's new habits, various forms of pots are needed to grow ornamental plants. Indoor planting requires a pot that has the main focus as an addition to the value of the beauty of the room and then followed by the value of the function. So the author creates a product set of pots with various kinds and shapes with the concept of space odyssey. This study used a design method with a quantitative approach which resulted in a design where the research process followed a planned procedure, with the concept of space odyssey. This supports the visual, material, and benefit aspects as a design analysis through the SCAMPER method with a discussion of design analysis using TOR (Terms of Reference). The design of this product also refers to indoor planting activities that have health benefits.
\end{abstract}

Keywords: space odyssey, planting, pot, decoration.

\section{PENDAHULUAN}

Selama masa pandemi kebiasaan masyarakat sepenuhnya berubah. Dari yang biasa melakukan kegiatan diluar rumah seperti bekerja dan bersekolah dimasa pandemi ini seluruh kegiatan dilakukan didalam rumah. Sehingga menciptakan kebiasan baru dikalangan masyarakat salah satunya yaitu bertanam dan medekorasi rumah. Kegiatan bertanam yang mengumpulkan tanaman hias dan juga menata tanaman untuk mendapatkan suasana baru dan membuat rumah lebih nyaman, baik untuk belajar, bekerja maupun untuk bercengkrama bersama keluarga. Meletakan 
tanaman hias sebagai dekorasi rumah memupunyai banyak manfaat salah satunya untuk Kesehatan. Kegiatan ini memiliki banyak manfaat kesehatan salah satunya meningkatkan daya tahan tubuh dan mengusir rasa jenuh dan stress sesuai dengan kondisi masyarakat saat ini yang lebih banyak menghabiskan waktu didalam rumah.

Perancangan set pot ini berkerjasama dengan PT. Artes Indonesia, salah satu perusahaan dibidang industri interior, produk homedecor dan karya seni berkualitas tinggi untuk ruang publik dan privat, baik itu dua dimensi atau tiga dimensi. yang berlokasi di Bandung, Jawa Barat. Perusahaan ini memiliki brand bernama UMA yang berfokus pada produk Homedecor yang memiliki konsep tentang luar angkasa (space odyssey).

Space odyssey merupakan pengembaraan luar angkasa yang ingin menceritakan cerita tentang rasa ingin tahu dan takut terhadap alam semesta yang luar biasa ini, \& mempertanyakan kelangsungan kehidupan manusia di bumi. PT. Artes Indonesia menerapkan Teknik Marble (Marbling) pada resin untuk menerapkan konsep yang dibuat pada produk yang dihasilkan. Produk yang telah dihasilkan berupa produk pot untuk tanaman yang dikeringkan dengan menggunakan material resin dan mempunyai ukuran rata-rata tinggi $5-10 \mathrm{~cm}$ dan diameter $5 \mathrm{~cm}$. Sedangkan kebutuhan pengguna saat ini menggunakan tanaman hidup dengan dimensi ukuran tumbuhan yang beragam.

Ditahun sekarang semakin banyak yang melakukan kegiatan bertanam dengan mengumpulkan dan merawat tanaman hias untuk mengisi waktu luang pada saat dirumah. Dengan kegiatan ini masyrakat menjadi lebih produktif dengan melakukan aktifitas bertanam dan membuat rumah menjadi nyaman. Dalam memenuhi kebutuhan kebiasaan baru masyarakat kegiatan bertanam dalam rumah sehingga membuat kebutuhan pot yang semakin meningkat dan untuk menambah ragam desain pot yang akan dihasilkan oleh PT.Artes Indonesia. Pada proses perancangan ini penulis mengambil Quasar sebagai konsep dalam perancangan. Quasar merupakan objek yang paling terang dialam semesta bahkan galaksinya sendiri tidak kelihatan. Dengan melakukan pendekatan kebutuhan user melalui konsep space odyssey diharapkan perancangan ini dapat memenuhi ragam desain yang dihasilkan oleh PT.Artes Indonesia serta produk yang dihasilkan memilik fokus utama sebagai penambah nilai keindahan ruangan lalu kemudian diikuti dengan nilai fungsi.

Tujuan perancangan ini bertujuan untuk menciptakan desain yang inovatif terhadap perancangan set pot, selain itu untuk menciptakan produk yang memiliki konsep yang berbeda dengan set pot yang beredar dipasaran.

\section{KAJIAN TEORI}

\section{Pot}

Kegiatan bertanam dalam ruangan masih menjadi berita besar, dalam memenuhi kebutuhan kebiasaan baru masyarakat bertanam sehingga membuat kebutuhan pot yang semakin meningkat. Pot merupakan salah satu wadah dimana tanaman hidup dan dibesarkan. Tanaman dalam pot juga dapat mempercantik rumah dan membuat suasana kekeluargaan semakin nyaman. Pot yang saat ini beredar di pasaran memiliki berbagai konsep, bentuk dan bahan. Pilihan pot bunga yang tepat tidak hanya dapat mempercantik komposisi tanaman, tetapi juga memengaruhi pertumbuhan tanaman.

\section{Menata Tanaman di Dalam Ruangan}

Jika Anda menggunakan berbagai tanaman untuk dekorasi, rumah yang bagus akan semakin indah. Selain faktor visual, tanaman hias yang ada di dalam rumah akan membuat udara di sekitar kita lebih segar. Disadari atau tidak, tanaman hias tampaknya memiliki kemampuan untuk menghidupkan energi di rumah. Dengan memperhatikan hal-hal tersebut maka tidak heran jika banyak sekali pecinta tanaman hias. Namun, itu tidak membantu jika Anda meletakkannya di mana saja.

\section{Jenis-Jenis Tanaman Hias Hidup}

Tanaman hias merupakan tanaman yang memiliki dua fungsi selain sebagai dekorasi, juga dapat digunakan untuk menyegarkan atau menyejukkan lingkungan atau ruangan tertentu. Tanaman hias meliputi semua tumbuhan baik berupa jamu, rambat, perdu, perdu atau pohon yang sengaja ditanam oleh masyarakat baik sebagai bagian dari taman, pekarangan rumah, dekorasi interior, ritual, tata rias/sandang, maupun sebagai komponen karangan bunga.

Saat ini yang paling menarik bagi masyarakat adalah tanaman hias jenis sukulen yang dimana jenis ini sangat cocok untuk jadikan dekorasi rumah dan juga cara perawatan yang mudah. Jenis tanaman ini cocok berada ditempat yang kering dan lembab untuk penyiraman bisa dilakukan 20-34 hari sekali. Sedangkan untuk cahaya matahari jenis tanaman ini dapat bertahan dengan cahaya matahari tidak langsung atau berada di dalam ruangan tetapi dianjur seminggu sekali dilakukan penjemuran agar daun tidak tumbuh kebawah.

\section{Kegiatan Bertanam dalam Ruangan}

Kegiatan bertanam merupakan kegiatan yang dapat 
dijadikan oleh siapa saja sebagai hobi. Selama pandemi, bertanam telah menjadi kebiasaan baru di masyarakat. Selama aktivitas di luar rumah masih terbatas, sebagian orang akan lebih banyak menghabiskan waktunya di rumah. Penyebaran virus corona yang tak hentihentinya menyebar membuat semua kesulitan dan membosankan untuk tinggal di rumah saja. Banyak kegiatan yang kembali membuat kita senang dan bersemangat, salah satunya adalah bertanam di rumah. Kegiatan ini adalah salah satu alternatif untuk menghabiskan waktu selama berada dalam rumah. Karena masyarakat membeli tanaman di rumah untuk bercocok tanam, hal ini berdampak pada penjual tanaman hidup dan pot. Serta mengumpulkan berbagai macam bentuk pot tanaman untuk menambah keindahan ruangan tempat kegiatan dilakukan.

\section{Dekorasi Rumah}

Dekorasi berasal dari kata dalam bahasa Inggris : "decorate" yang artinya menghiasi sedangkan "decoration" berarti hiasan (Shadilly, 2006). Dari arti tersebut diambil pengertian bahwa dekorasi sangat berkaitan dengan aktivitas menghias dengan tujuan mempercantik sesuatu. Echols \& Shadily juga menambahkan pengertian dekorasi interior, "interior decoration generally refers to something that deals with finishes, surfaces, furniture and wall coverings" yang artinya dekorasi interior terkait dengan sesuatu tentang finishing (pengecatan pelapisan), pengolahan permukaan perabot dan juga pelapisan dinding.

\section{Tinjauan Desain}

\section{1). Konsep Visual}

Pada penelitian ini penulis mengangkat konsep Quasar pada space odyssey yang digunakan PT.Artes Indonesia pada brand UMA. "Space Odyssey" adalah sebuah perjalanan luar angkasa yang ingin bercerita tentang keingintahuan dan ketakutan akan alam semesta yang luar biasa, serta mempertanyakan keberlangsungan kehidupan manusia di Bumi. Alam semesta adalah wilayah yang sangat luas, penuh dengan berbagai komponen, galaksi, dan fenomena luar biasa. Pada proses perancangan ini penulis mengambil Quasar sebagai konsep utama dalam perancangan yang akan diterapkan pada produk yang dirancang. Quasar merupakan objek yang paling terang dialam semesta bahkan galaksinya sendiri tidak kelihatan dan quasar bisa menciptakan gerhana sendiri digalaksinya dan merupakan objek luar angkasa yang paling besar. Dengan adanya konsep ini dihapkan bisa menstimulus proses desain dengan penambahan value space odyssey agar produk yang dihasilkan dapat bercerita.

\section{2). Warna}

Teori warna pada buku (Olds, 2000) diperlukan harmoni warna berdasarkan terminologi dan aturan dasar warna yang dapat membantu pada pemilihan warna dan proses perpaduannya. Dari penjelasan diatas dapat ditarik kesimpulan warna yaitu kehadiran pigmen pada permukaan benda mempengaruhi pantulan cahaya tertentu. Berikut ini adalah jenis-jenis skema warna:
a.Neutral
b.Monokromatik
c.Analog
d.Komplementer.

\section{3). Bentuk}

Pada buku (Hannah, 2002) ada tiga poin penting pada karya bentuk tiga dimensi yaitu subordinate, dominant, dan subdominant. Ketiga hal ini didasari oleh sumbu simetri $\mathrm{x}, \mathrm{y}, \mathrm{z}$ yang memisahkan arah pada bentuk tiga dimensi. Perhatian harus diberikan pada proporsi keseluruhan, sifat permanen, dan bentuk komparatif harus diwaspadai karena berpengaruh pada ukuran panjang, ketebalan, maupun lebar. Membentuk tentunya dimulai dengan desain berupa gambar, dimana Yuswanti (dalam Nainggolan, 2019: 213) mengungkapkan bahwa "gambar adalah sesuatu yang diwujudkan secara visual dalam bentuk dua dimensi sebagai curahan atau pikiran.

\section{4). Material}

Material adalah sesuatu hal yang disusun dan dibuat oleh bahan menurut (William, 2004) (Mulyadi, 2000) menjelaskan material adalah bahan baku yang diolah perusahaan industri diperoleh dari pembelian lok al, import, atau yang dilakukan sendiri.

\section{Profil Perusahaan}

PT. Artes Indonesia adalah perusahaan dibidang industri interior, produk homedecor dan karya seni berkualitas tinggi untuk ruang publik dan privat, baik itu dua dimensi atau tiga dimensi. yang berlokasi di Bandung, Jawa Barat. Perusahaan ini didirikan pada tahun 2012 oleh sekelompok seniman dan desainer muda di Bandung dan di pimpin oleh Aurora Rintya Ayuningrum selaku Founder \& CEO PT.Artes Indonesia. Perusahaan ini memiliki brand bernama UMA yang berfokus pada produk-produk homedecor. UMA adalah proyek Artes Indonesia berfokus pada produk rumah tangga dan kehidupan yang dibuat oleh ahli pengrajin \& dirancang sebagai bagian pernyataan untuk ruang Anda. Melalui koleksi ini para desainer ingin berbagi cerita tentang keingintahuan dan ketakutan terhadap hal luar biasa ini alam semesta, \& mempertanyakan kelangsungan hidup manusia di bumi. Dalam setiap koleksinya UMA akan menyajikan kepada 
konsumen cerita yang berbeda dibungkus dalam bentuk yang menarik dengan harapan berfungsi sebagai interpretasi aktif Anda kehidupan sehari-hari.

\section{METODE PENELITIAN}

\section{Metode Penelitian}

\section{1). Pendekatan Penelitian}

Pada perancangan ini menggunakan metode penelitian kualitatif dengan cara hipotesa keaadaan. Menurut (Gunawan, 2013) metode kualitatif merupakan metode yang berusaha menafsirkan tingkah laku manusia adalah perspektif peneliti dengan tujuan memahami objek secara mendalam untuk mengembangkan konsep sensitivitas yang berkaitan dengan studi kasus yang akan dibahas. Langkah selanjutnya adalah melakukan analisis dengan mencari data hipotesis dari analisis lingkungan sekitar, observasi langsung dan sumber berita elektronik tentang maraknya kegiatan bercocok tanam dan mengumpulkan tanaman hias.

\section{2). Pendekatan Penelitian}

Pada perancangan kali ini, teknik pengumpulan data melalui metode observasi, wawancara, survei langsung dan melalui sumber berita elektronik. Metode observasi dilakukan dengan obeservasi online dengan melihat dan mengamati kegiatan sehari-sehari user yang berada di halaman instagram dan youtube user. Hal ini dilakukan agar mengetahui apa saja kegiatan selama dimasa pandemi dan juga kelebihan dan kekurangan dari pruduk yang telah digunakan user. Sedangkan metode wawancara lebih menekankan pada keefektifan produk yang nantinya akan digunakan oleh masyarakat atau target pengguna. Wawancara langsung dilakukan peneliti akan berfokus pada wawancara bebas, karena akan membuat suasana lebih bersahabat tetapi tepat fokus pada tujuan. Wawancara dilakukan kepada beberapa orangdengan kisaran umur 20-30 tahun pada ruang lingkup PT.Artes Indonesia, beberapa kerabat dekat dan beberapa penjual pot dan bunga. Tujuan dari wawancara ini supaya mendapatkaninformasi dan data empirik pada penelitian yang dikaji. Selain observasi pada halaman sosial media pengumpulan data juga dilakukan melalui berita elektronik.

\section{Metode Perancangan}

\section{1). Pendekatan Perancangan}

Perancangan pada produk ini penulis menggunakan pendekatan melalui wawancara kepada beberapa orang yang berumur 20-30 tahun agar mengetahui aktivitas yang dilakukan user selama beraktivitas dari rumah. Dari wawancara tersebut penulis dapat menyimpulkan kebutuhan apa saja yang dibutuhkan penggunakan dengan kebiasaan yang telah dilakukan selama beraktifitas dari rumah.Penulis juga mempertimbangan segi visual agar dapat diterima dan digunakan oleh gender apapun dan juga tidah hanya sebagai wadah tanaman, juga memiliki nilai keindahan yang akan membuat ruang lebih nyaman dengan visual konsep yang diterapkan pada produk ini. Dari segi visual penulis juga mempertimbangkan dari material yang akan dipakai agar kuat dan tahan lama serta Teknik yang digunakan dapat menerapkan konsep dengan baik pada permukaan produk, dan juga melihat produk competitor yang sudah ada dipasar dari segi ukuran agar ukuran tersebut standar dan nyaman digunakan oleh pengguna.

\section{2). Teknik Analisi Data}

Bentuk analisis SCAMPER dinilai tepat pada perancangan produk ini. Hal ini dipengaruhi oleh banyaknya proses kreatif yang dilakukan, seperti ada atau tidaknya pilihan lain seputar visual, material, dan operasi; penggabungan ide dan konsep produk referensi; adaptasi ide; sebagai modifikasi produk, Perubahan yang lebih baik dari produk sejenis Bentuk; penggunaan produk lainnya; penghapusan atau penambahan elemen produk untuk mengoptimalkan fungsi produk secara lebih spesifik dan efektif; dan penataan ulang komponen dan fungsi produk.

\section{HASIL DAN PEMBAHASAN}

1.Hasil

\section{1). Existing Products}

Tabel 1. Tabel Existing Products

\begin{tabular}{|c|c|}
\hline & \multirow{2}{*}{$\begin{array}{l}\text { Penempatan produk: } \\
\text { Indoor dan outdoor. } \\
\text { Visual produk } \\
\text { Mempunyai berbagai warna } \\
\text { tetapi lebih dominan pot } \\
\text { berwana putih }\end{array}$} \\
\hline & \\
\hline & $\begin{array}{l}\text { Kondisi Lingkungan : } \\
\text { Karena dapat digunakan di } \\
\text { dalam dan luar ruangan, } \\
\text { penempatan produkini } \\
\text { harus terkena papasaran } \\
\text { sinar Matahari agartanaman } \\
\text { tetap segar. }\end{array}$ \\
\hline & Material : Plastik \\
\hline & $\begin{array}{l}\text { Penempatan produk: } \\
\text { Indoor dan outdoor. }\end{array}$ \\
\hline & $\begin{array}{l}\text { Visual Produk : } \\
\text { Menggunakan warna asli } \\
\text { darimaterial }\end{array}$ \\
\hline & $\begin{array}{l}\text { Kondisi Lingkungan : } \\
\text { Sirkulasi udaranya yang } \\
\text { sangat bagus,sehingga tidak }\end{array}$ \\
\hline
\end{tabular}




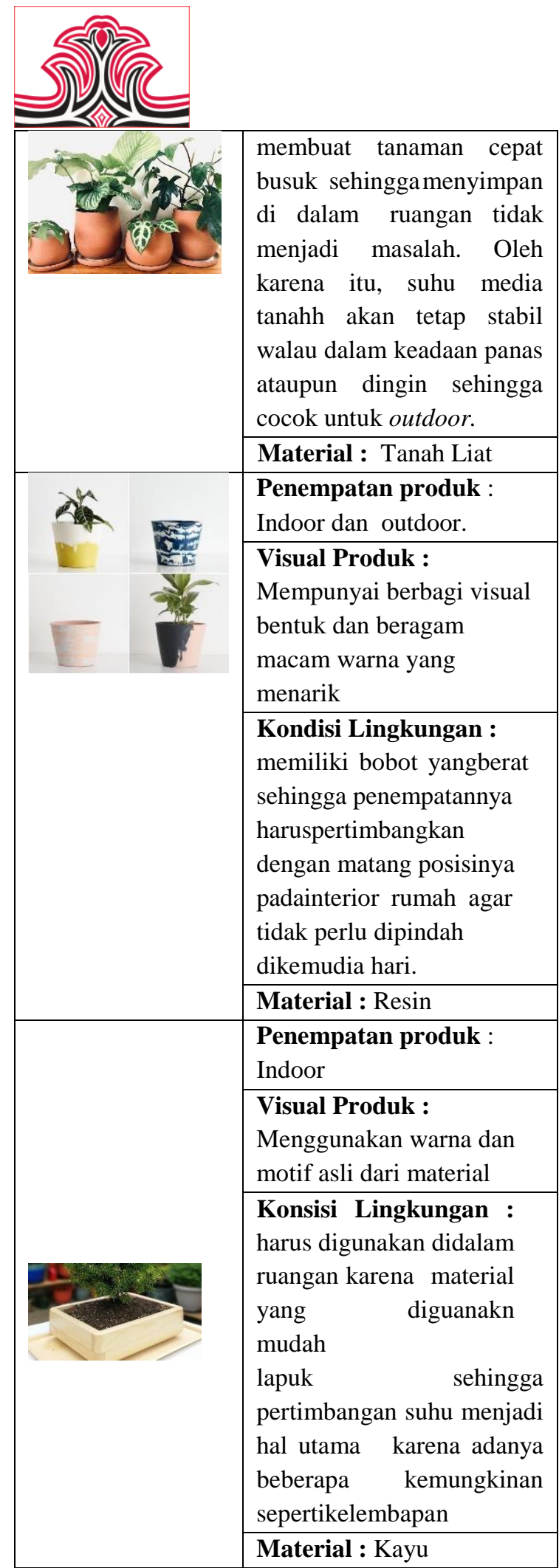

\section{2). Tabel Parameter Desain}

Penerapan metode dari SCAMPER untuk produk ini dengan mengkomparasikan keempat existing products diantaranya:

- Subtitute: penggunaan material semen

- Combine: penempatan produk ini bisa dikombinasikan dengan produk lain seperti meja, piano sehingga menambah nilai keindahan ruangan

- Adapt: Mengadaptasi konsep dari benda-benda luar
Gorga : Jurnal Seni Rupa

Volume 10 Nomor 02 Juli-Desember 2021 p-ISSN: 2301-5942 | e-ISSN: 2580-2380

angkasa

- Modify - Magnify - Minify : memodifikasi bentuk sesuai dengan konsep

\section{3). Hipotesa Desain \\ (1). SWOT}

Tabel 2. Tabel Strenghts dan Opportunities

\begin{tabular}{|l|l|}
\hline Strenghts & Opportunities \\
\hline Memiliki bentuk dan & Memiliki bentuk dan \\
warna yang menarik & warna yang menarik \\
Perawatan dan & Perawatan dan \\
penempatan produk & penempatan produk \\
yang mudah & yang mudah \\
Membuat ruangan & Membuat ruangan \\
leboh indah dan udara & leboh indah dan \\
menjadu bersih & udara menjadi bersih \\
\hline Weaknesses & Threats \\
\hline - Produk yang & Rentan pecah jika \\
gampang rusak & terjatuh karena \\
apabila terjatuhdari & karakteristik semen \\
ketinggian & yang padat namun \\
- Pengembangan & tidak elastis. \\
bentuk produk & \\
yang kurang & \\
beragam & \\
\hline
\end{tabular}

\section{(2). TOR}

Adapun hasil eksplorasi lanjutan yang sudah diaplikasikan pada kain berdasarkan hasil pertimbangan eksplorasi yang telah dilakukan sebelumnya, sebagai berikut:

\section{a. Pertimbangan Desain}

- Masyakarat beranggapan dengan meletakan tanaman hias dalam rumah memberi banyak manfaat salah satunya membuat udara diruangan menjadi lebil segar

- Membuat produk dekorasi rumah yang tidak hanya berfungsi sebagai wadah tenaman tetapi juga mempunyai nilai keindahan

- Pemilihan material yang digunakan dapat menyerap air dengan baik.

\section{b. Batasan Desain}

- Bentuk produk set pot ini terinspirasi bentuk Quasar yang disederhanakan

- Penerapan motif marbling pada produk hanya ditinjau dari aspek rupa ;warna saja yang memiliki ciri khas dari objek luar angkasa yang dipilih.

\section{c. Deskripsi Produk}

Konsep yang diterapkan pada produk ini sesuai dengan kebutuhan user yang mengingkan produk yang tidak 


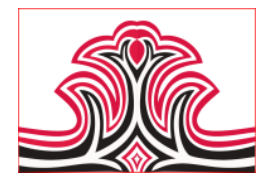

hanya berfungsing sebagai wadah tanaman tetapi juga memiiki nilai keindahan untuk dekorasi rumah. Penerapan bentuk geometris membuat produk lainnya yang berada di dalam ruangan sama bisa saling berhubungan.

\section{Pembahasan}

1). Mind Mapping

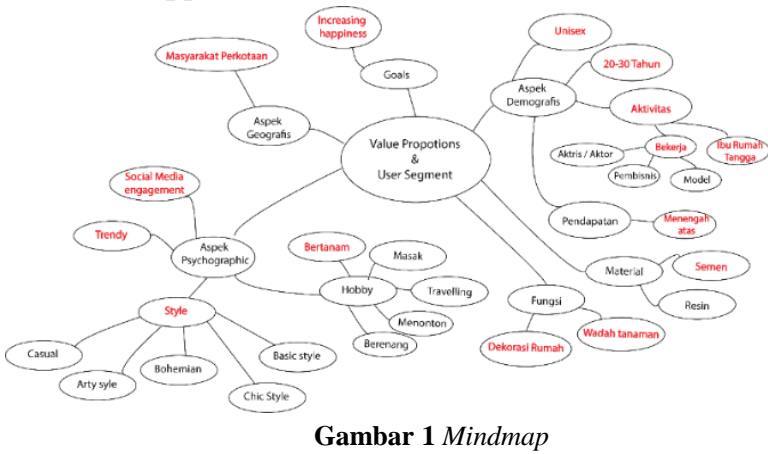

Gorga : Jurnal Seni Rupa

Volume 10 Nomor 02 Juli-Desember 2021 p-ISSN: 2301-5942 | e-ISSN: 2580-2380

4). Desain Final
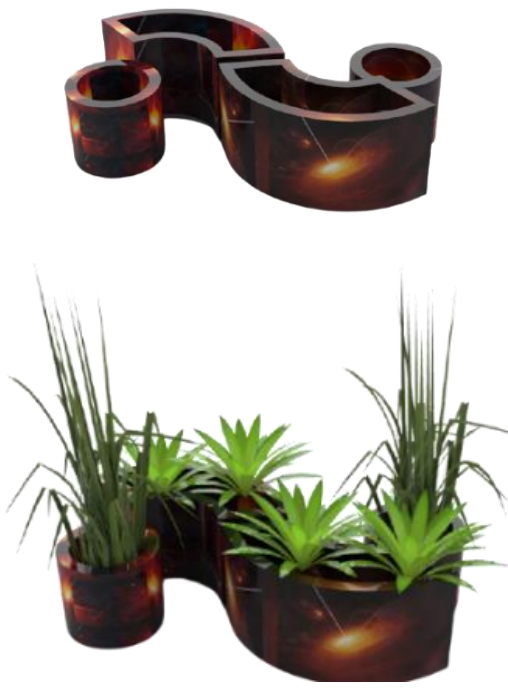

Gambar 4. Desain Final

\section{5). Final Produk}

\section{2). Moodboard}

436

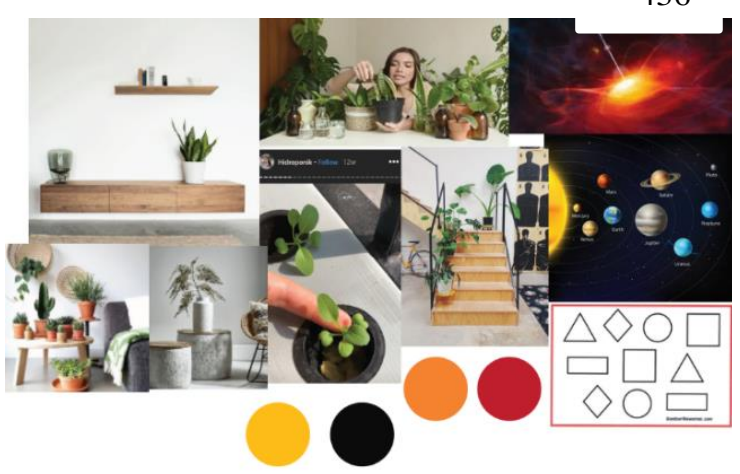

Gambar 2. Moadboard

\section{3). Desain Alternatif}
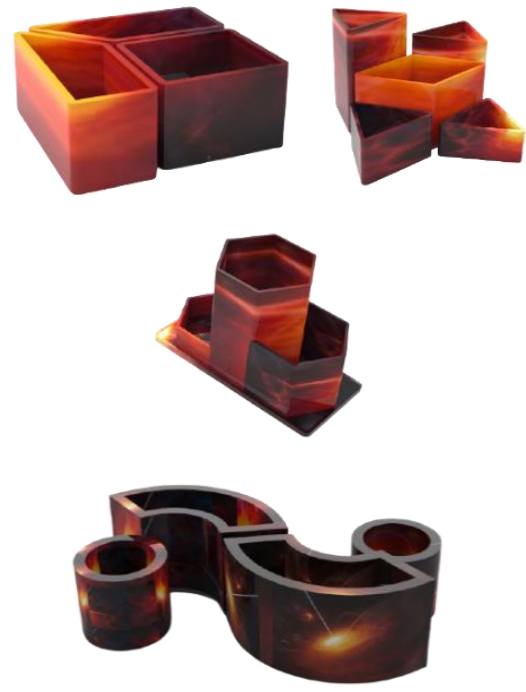

Gambar 3. Desain Alternatif
437
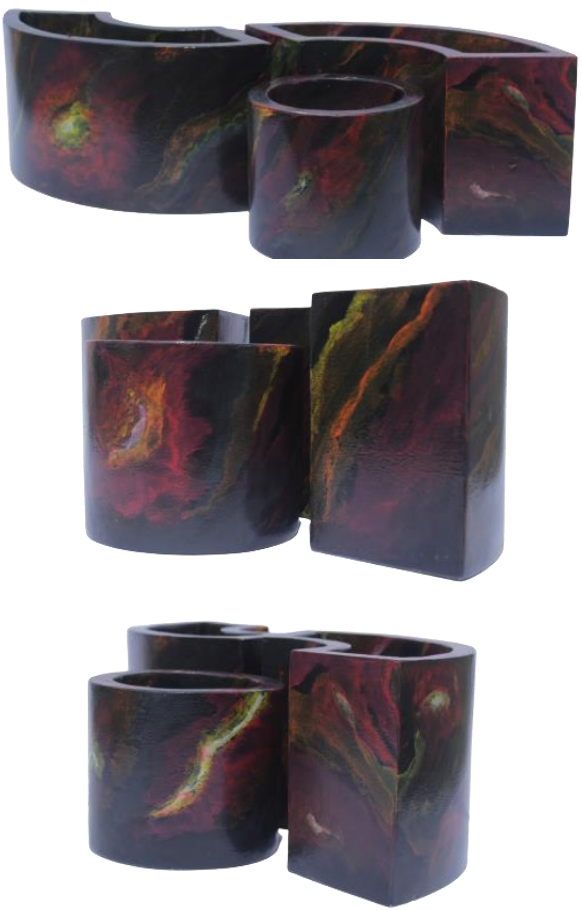

Gambar 5. Final Produk

\section{6). Operasional Produk}

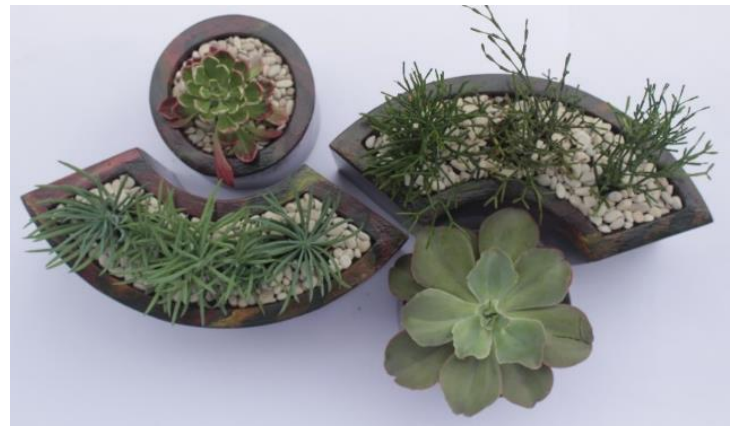

Gambar 6. Operasional Produk 


\section{KESIMPULAN DAN SARAN}

\section{Kesimpulan}

Perancangan set pot dengan kebutuhan user melalui konsep space odyssey ini diharapkan bisa menambah berbagai jenis pot pada PT.Artes Indonesia. Selain itu, visualisasi produk yang menarik menghasilkan produk yang tidak hanya sebagai wadah tenaman tetapi juga memberi keindahan untuk ruangan atau sebagai dekorasi rumah. Berdasarkan penelitian dan hasil perancangan yang telah dibuat, konsep yang diterapkan menggunakan color tone bold dengan warna merah garnet, bright orange, yellow fire, dan warna hitam. Penempatan produk ini berada di dalam ruangan dan disesuikan dengan kondisi interior rumah.

\section{Saran}

Perancangan Produk Set Pot Quasar ini masih banyak perlu inovasi mulai dari data yang telah digunakan hingga perancangan pada produknya sendiri. Dalam komunikasi antar vendor dan penulis perlu ditingkatkan lagi guna mengahsilkan produk yang sesuai. Penulis menyadari bahwa penelitian ini masih sangat sederhana dan jauh dari kata sempurna, namun penulis berharap tulisan ini bisa menjadi referensi awal bagi siapapun yang mempunyai keinginan untuk melakukan penelitian selanjutnya dengan topik dan tujuan yang sama. Lebih dan kurangnya penulis mengharapkan sskritik dan saran yang membangun.

\section{DAFTAR RUJUKAN}

Gunawan, I. (2013). Metode Penelitian Kualitatif. Malang: Fakultas Ilmu Pendidikan Universitas Negeri Malang.

Hannah, G. G. (2002). Elements of Design : Rowena Reed Kostellow and the Structure of Visual Relationships. New York: Princeton Architectural Press.

Mulyadi. (2000). Akuntansi Biaya. Yogyakarta: Aditya Media.

Nainggolan, M., Silaban, B., \& Azis, A. C. K. (2018). Analisis Karya Gambar Bentuk Siswa Kelas VII SMP Negeri 1 Simangumban Berdasarkan Prinsip-Prinsip Seni Rupa. Gorga: Jurnal Seni Rupa, 7(2), 212217.

Olds, A. R. (2000). Child Care Design Guide. (p.213268). New York: McGraw-Hill Professional.

Shadilly, J. M. (2006A). Kamus Inggris-Indonesia Cetakan XXVIII. Jakarta: PT. Gramedia.

William, C. \&. (2004). Material Science and Engineering An Introduction. Third Edition. New York: John Willy and Sons. 